\title{
ISOLATED INTERMEDIATES - PRODUCTS OF LONG DISTANCE GENE DISPERSAL, PHANTOM HYBRIDITY OR CONVERGENT EVOLUTION? THE CASE OF THE HALF-BARKED EUCALYPTUS AMYGDALINA.
}

\author{
by J.B. Kirkpatrick and B.M. Potts
}

(with two tables and six text-figures)

\begin{abstract}
KIRKPATRICK, J.B. \& POTTS, B.M., 1987 (30:vi): Isolated intermediates - products of long distance gene dispersal, phantom hybridity or convergent evolution? The case of the half-barked Eucalyptus amygdalina. Pap. Proc. R. Sec. Tusm., 12I: 15-22. https://doi.org/10.26749/rstpp.121.15 ISSN 0080-4703.Department of Geography and Department of Botany, University of Tasmania, Hobart, Tasmania.
\end{abstract}

Apparent intermediates between Eucalyptus amygdalina and E. pulchella occur well outside the recognized range of the latter species. Progenies of these isolated intermediates were grown in uniform conditions with progenies of trees of E. pulchella, E. amygdalina and apparent hybrids between these two species that are found where they occur parapatrically. The isolated intermediate population proved identical with E. amygdalina in seedling characteristics, while the parapatric intermediates were more variable than the other populations, this variability probably being partly the result of hybridization between $E$. amygdalina and either E. tenuiramis or $E$. risdonii. The allopatric intermediate population is more likely to have resulted from convergence of E. amygdalina in the direction of $E$. pulchella than from phantom hybridity or long distance gene migration.

Key Words: convergent evolution, Eucalyptus, gene dispersal, phantom hybrids.

\section{INTRODUCTION}

Species in the genus Eucalyptus, like many of those in Quercus, Poa, Hieracium and Pinus, tend to have blurred boundaries where they have parapatric distributions with their nearer relatives. Hybridization, intergradation and multidimensional clinal variation abound within the eucalypt subgenera (e.g. Pryor \& Johnson 1971, Potts \& Reid 1985a), bedevilling the taxonomist, but providing an excellent laboratory for biogeographic and evolutionary investigation (e.g. Barber 1955, Barber \& Jackson 1957, Kirkpatrick et al. 1973, Moran \& Hopper 1983, Potts \& Reid 1985b). These patterns of variation may also provide evidence relevant to palaeoenvironmental reconstruction (e.g. Schlarbaum et al. 1982, Adams 1983), rarely exploited by the historical biogeographer and palaeontologist.

One of many patterns of spatial variation evident in Eucalyptus is a scattering of stands of individuals that are intermediate between one recognized species and another recognized species, within the range of only one of the recognized species (Pryor 1951, 1955, Pryor \& Johnson, 1971, Ashton \& Williams 1973, Parsons \& Kirkpatrick 1972, Kirkpatrick et al. 1973, Kirkpatrick 1977a, Shaw et al. 1984). The most popular hypothesis to explain the existence of such stands is environmental change sufficient to eliminate one parent but not its hybrids with the other parent. This hypothesis has been established as reasonable in some cases (e.g. Kirkpatrick et al. 1973), but in other cases has faded under close examination (e.g. Kirkpatrick 1977a). One alternative to the phantom hybrid hypothesis is long distance dispersal by hybridization (Potts \& Reid 1983, Potts \& Jackson 1986). Pollen can travel further than eucalypt seeds, which are relatively heavy and have no apparent adaptations for long distance dispersal (Cunningham 1960, Kirkpatrick 1977b, Macphail 1979). The migration through hybridization hypothesis implies that the migrating species is locally expanding its range in response to environmental change (e.g. Potts 1986), whereas the phantom hybrid hypothesis implies local contraction. Thus, both hypotheses could be correct within the range of one species, and evidence independent of the phenetic and genetic characteristics of the isolated intermediate populations and their putative parents is usually needed to establish which is the more reasonable hypothesis for any one stand.

However, the phantom hybrid and migration through hybridization hypotheses do not constitute 
all the options. Allopatric intermediate populations may represent ancestral cline forms linking both taxa or alternatively, characteristics of one species may have been independently selected from the gene pool of another species. In the case of such convergence it could be expected that not all characters of the plant would necessarily converge and that within-population and within-parent genetic variability would not be as high as could be the case in the initial phases of phantom hybridity and migration through hybridization.

There have been dramatic changes in environment in Tasmania in the last 17,000 years, it being only in the last 10,000 years that climatic patterns have approximated those of today (Macphail 1979). Glacial depositional evidence suggests that temperatures were $6^{\circ} \mathrm{C}-7^{\circ} \mathrm{C}$ colder in Tasmania at the height of the Last Glacial than at present (Kiernan 1983). Given this drop in temperature, a vast expansion of the area climatically incapable of supporting trees must have occurred between the onset and the peak of the Last Glacial, creating a large and long term barrier to the movement of species and their genes from the southeast of Tasmania to the north of Tasmania and vice versa

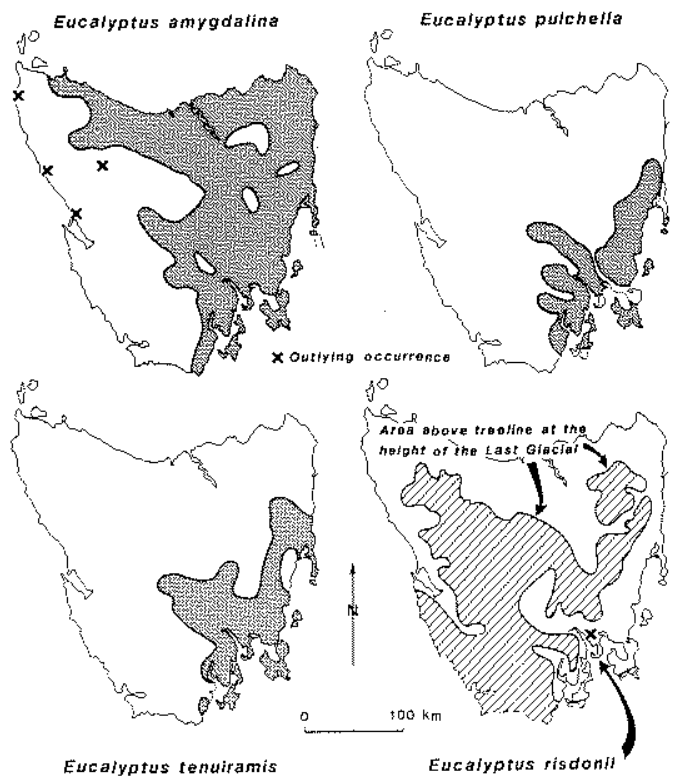

FIG. 1 - The distributions of Eucalyptus amygdalina, E. pulchella, E. risdonii and E. tenuiramis generalised from the dot distribution maps in Kirkpatrick \& Backhouse (1985), and the approximate location of the climatic treeline at the height of the Last Glacial (Kirkpatrick 1986). (fig. 1). The distribution of many of the endemic species suggests confinement to a southeastern glacial refuge (Kirkpatrick \& Brown 1984, Potts \& Reid 1985a). This is clearly seen in the endemic Piperitae species (informal subseries Amygdalininae, subgenus Monocalyptus - Pryor \& Johnson 1971) where the endemics E. risdonii, E. tenuiramis and E. pulchella exhibit distinctly southeastern distribution patterns (fig. 1, Ladiges et al. 1983).

The lowland Piperitae species are strongly ecologically segregated in the southeast (e.g. Hogg \& Kirkpatrick 1974). Eucalyptus pulchella is virtually confined to dry dolerite hills whereas $E$. tenuiramis and $E$. risdonii generally occur on soils developed on mudstone, although toward the east, E. tenuiramis may occur on dolerite hills where it grows with a glaucous (as opposed to green) variant of $E$. pulchella. Eucalyptus risdonii is geographically localized and occurs on the drier and shallower mudstone soils and appears to be a neotenous form of E. tenuiramis (e.g. Ladiges et al. 1983). Eucalyptus amygdalina, by contrast, is geographically widespread (fig. 1) and tends to be more an edaphic generalist, although in the southeast it generally occurs on soils derived from sandstone or mudstone. Further north however, $E$. amygdalina occurs on many sites which superficially appear suitable for E. tenuiramis or E. pulchella (e.g. Kirkpatrick \& Brown 1984). In the case of $E$. pulchella, this apparent incomplete range expansion may be attributed to its inability to occupy soils formed on substrata other than dolerite (Hogg \&

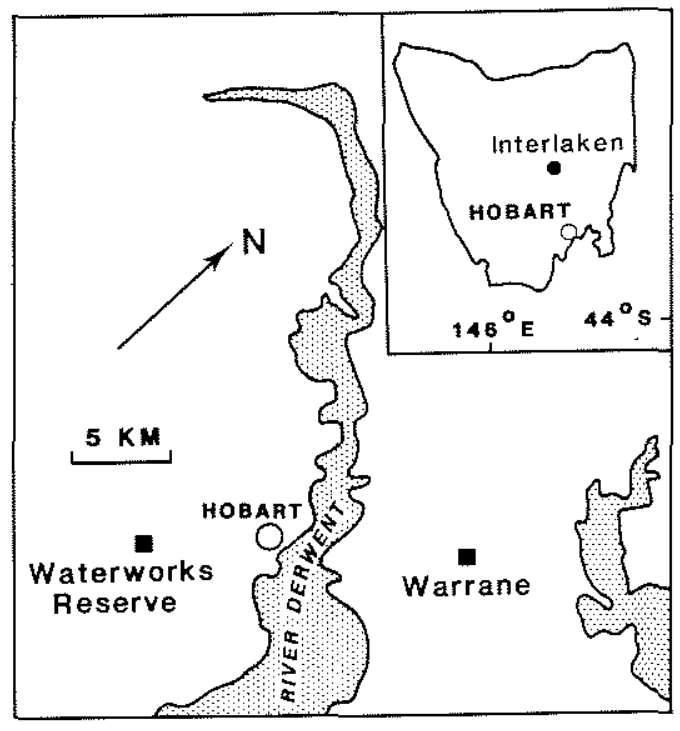

FIG. 2 - Locations of sample sites. 


\section{TABLE 1}

\section{The main characters defining the Tasmanian Piperitae species Eucalyptus amygdalina, $E$. pulchella, E. tenuiramis and E. risdonï from Curtis \& Morris 1975).}

\begin{tabular}{|c|c|c|c|c|}
\hline Characters & E. amygdalina & E. pulchella & E. tenuiramis & E. risdonii \\
\hline $\begin{array}{l}\text { juvenile } \\
\text { leaves }\end{array}$ & $\begin{array}{l}\text { opposite } \\
\text { sessile to } \\
\text { shortly petiolate } \\
\text { lanceolate } \\
\text { pale green }\end{array}$ & $\begin{array}{l}\text { opposite becoming } \\
\text { alternate } \\
\text { sessile to shortly } \\
\text { petiolate } \\
\text { linear } \\
\text { green to subglaucous }\end{array}$ & $\begin{array}{l}\text { opposite } \\
\text { perfoliate } \\
\text { ovate-lanceolate } \\
\text { very glaucous }\end{array}$ & $\begin{array}{l}\text { opposite } \\
\text { perfoliate } \\
\text { ovate-lanceolate } \\
\text { very glaucous }\end{array}$ \\
\hline $\begin{array}{l}\text { adult } \\
\text { leaves }\end{array}$ & $\begin{array}{l}\text { alternate } \\
\text { shortly petiolate } \\
\text { lanceolate to } \\
\text { narrow linear } \\
60-120 \times 7-10 \mathrm{~mm} \\
\text { green to sub- } \\
\text { glaucous }\end{array}$ & $\begin{array}{l}\text { alternate } \\
\text { shortly petiolate } \\
\text { narrow linear to } \\
\text { linear-falcate } \\
50-120 \times 3-5 \mathrm{~mm} \\
\text { green to sub- } \\
\text { glaucous }\end{array}$ & $\begin{array}{l}\text { alternate } \\
\text { petiolate } \\
\text { elliptical to } \\
\text { lanceolate-falcate } \\
50-160 \times 1-35 \mathrm{~mm} \\
\text { glaucous }\end{array}$ & $\begin{array}{l}\text { juvenile leaves } \\
\text { usuaily persistent } \\
\text { in adult stage } \\
\text { pair } 60-100 \mathrm{~mm} \text { long } \\
\text { glaucous }\end{array}$ \\
\hline buds/umbel & $5-12$ & $5-12$ & $7-23$ & $5-15$ \\
\hline buds & $\begin{array}{l}\text { pedicellate } \\
\text { clavate }\end{array}$ & $\begin{array}{l}\text { shortly pedicellate } \\
\text { clavate }\end{array}$ & $\begin{array}{l}\text { shortly pediceliate } \\
\text { clavate }\end{array}$ & $\begin{array}{l}\text { pedicellate } \\
\text { clavate }\end{array}$ \\
\hline operculum & hemispherical & hemispherical & $\begin{array}{l}\text { flattened to sub- } \\
\text { conical }\end{array}$ & hemispherical \\
\hline capsules & $\begin{array}{l}\text { pyriform-truncate to } \\
\text { nearly hemispherical } \\
4-6 \mathrm{~mm} \text { diameter }\end{array}$ & $\begin{array}{l}\text { pyriform-truncate to } \\
\text { nearly hemispherical } \\
5-6 \mathrm{~mm} \text { diameter }\end{array}$ & $\begin{array}{l}\text { pyriform-truncate to } \\
\text { hemispherical } 7-11 \\
\text { mm diameter }\end{array}$ & $\begin{array}{l}\text { pyriform-truncate to } \\
\text { hemispherical } 8-10 \\
\text { mm diameter }\end{array}$ \\
\hline bark & $\begin{array}{l}\text { rough fibrous, dark } \\
\text { grey usually persis- } \\
\text { tent sometimes } \\
\text { deciduous on upper } \\
\text { regions }\end{array}$ & $\begin{array}{l}\text { deciduous trunk } \\
\text { smooth white or } \\
\text { with bluish streaks }\end{array}$ & $\begin{array}{l}\text { deciduous trunk } \\
\text { smooth greyish- } \\
\text { white }\end{array}$ & $\begin{array}{l}\text { deciduous trunk } \\
\text { smooth ashy-grey } \\
\text { colour cream streaks }\end{array}$ \\
\hline habit & $\begin{array}{l}\text { mallee or tree to } \\
20 \mathrm{~m}\end{array}$ & tree $6-15 \mathrm{~m}$ & $9-25 \mathrm{~m}$ tree & $\begin{array}{l}\text { mallee or tree to } \\
15 \mathrm{~m}\end{array}$ \\
\hline
\end{tabular}

Kirkpatrick 1974, Brown \& Bayly-Stark 1977 , Harris \& Kirkpatrick 1982), the presence of a broad band of soils on sedimentary rocks between the southeastern and northern lowlands coupled with relatively poor dispersal ability and insufficient time since deglaciation (Kirkpatrick \& Brown 1984). Yet, throughout the E amygdalina forests on dolerite in the north and northeast of the state there can be found groups of trees with varying proportions of deciduous bark and with adult leaves as narrow as those of E. pulchella. Eucalyptus pulchella and E. amygdalina are virtually identical in reproductive characters. Vegetative and bark characters define their difference (table 1). The few of these trees that have totally deciduous bark appear identical to the trees in the populations of $E$. pulchella in southeastern Tasmania.

The degree of isolation of these intermediates from populations of $E$. pulchella made the hypothesis of long distance hybridization particularly relevant. This paper addresses the problem of the origin of these intermediate populations by comparing the characteristics and variability of the progeny of one stand of isolated intermediates with those of the progeny of the putative parent species and with those of the apparent hybrids that occur where these two species have contiguous distributions. 


\section{METHODS}

Collections of adult leaves and mature capsules were made from five trees of Eucalyptus amygdalina on mudstone at Warrane (AmW), five trees of E. pulchella on mudstone at Warrane $(\mathrm{PmW})$, seven apparent hybrids between the two species from mudstone at Warrane ( $\mathrm{HmW})$, five trees of E. pulchella from dolerite at Warrane $(\mathrm{PdW})$, five trees from a population of isolated intermediates on dolerite on the Interlaken-Tunbridge road $(\mathrm{Hdl})$, and from one tree of $E$. pulchella (PsR), one tree of E. amygdalina (AsR) and one adjacent putative hybrid between the two species (HsR) on sandstone at the Waterworks Reserve, Hobart (fig. 2). Length and width were measured for five sun leaves taken from the region of maximum spring/summer growth per tree.

Seedlings of the above trees were grown by parent in ten totally randomized blocks of thirty with two seedlings in each pot. A loam-based potting mix was used. After three months of growth in a glasshouse the following measurements were made on each seedling: height; number of fully expanded nodes on the main stem; number of lateral shoots with expanded leaves; length of the longest lateral shoot; first leaf pair with an intranode; the length of the internode between the fifth and sixth leaf pairs; length, and width of one of each of the second, fourth and sixth leaf pairs. The number of seedlings per parent varied from 6 to 20 , but for most parents was between 18 and 20 . A few obvious 'runts' (i.e. stunted plants) were excluded from measurement. Such plants are frequently found at low frequencies in eucalypt progenies (e.g. Potts \& Reid 1983) even from pure species. In the present case there was no marked difference between populations in the frequency of these plants.

Means and coefficients of variation were calculated for the ratio between the length and width of the fourth leaf pair, internode length, seedling height, the ratio between the length of the longest lateral shoot and height, the ratio between the number of lateral shoots and twice the number of expanded nodes on the main stem, and the number of expanded nodes. Means for the leaf length/ width at node four and intranode development from 18 progeny from each of four trees of E. risdonii and one tree of E. tenuiramis were available from a previous experiment conducted in similar conditions (Potts \& Reid 1985b).

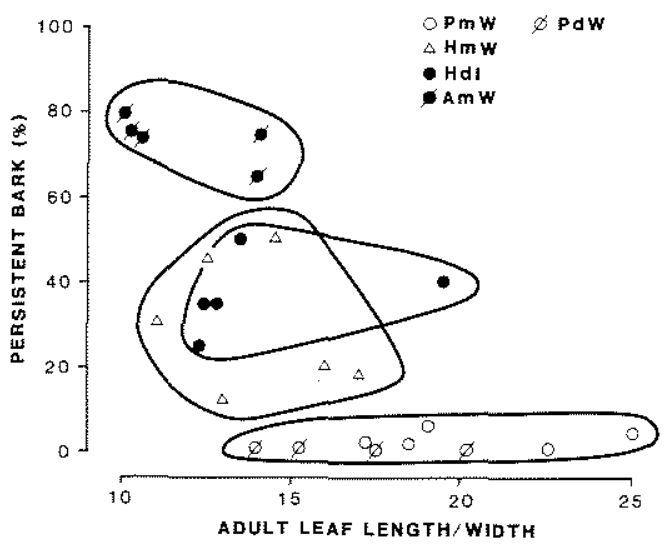

FIG. 3 - The pattern of variation in the adult phenotype $(P=$ Eucalyptus pulchella, $A=\mathrm{E}$. amygdalina, $H=$ intermediate or hybrid, $m=$ mudstone, $d=$ dolerite, $W=$ Warrane, $I=$ Interlaken).

\section{RESULTS}

\section{Adult Morphology}

The population of intermediates (HdI) and the putative hybrids $(\mathrm{HmW})$ clearly lie between the populations of Eucalyprus amygdalina and $E$. pulchella in the differentiating characteristics of the adult phenotype (fig. 3 ).

\section{Seedling Morphology}

There was no overlap in progeny means between Eucalyptus amygdalina (AmW) and the two E. pulchella populations in leaf length/width at the fourth node, internode length and the proportion of seedlings with intranodes and there was little overlap in the number of expanded nodes (fig. 4). The progenies from the population of isolated intermediates ( $\mathrm{Hdl}$ ) were distinct from the E. pulchella progenies in these characters. They had extreme mean values for several variables (fig. 4 ), but for most characters differentiating $E$. amygdalina and E. pulchella, the HdI progenies clearly had close affinities to E. amygdalina (fig. 5). The progeny means of the putative hybrids from Warrane $(\mathrm{HmW})$ varied between and even transgressed the range of variation between $E$. pulchella and E. amygdalina. Rather than lying intermediate between $E$. pulchella and E. amygdalina, the progeny means tended to lie close to one or other putative parent. HsR, the putative hybrid between 


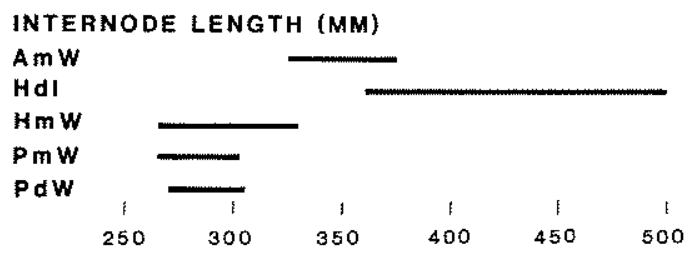

LEAF LENGTH/WIDTH 4 TH NODE

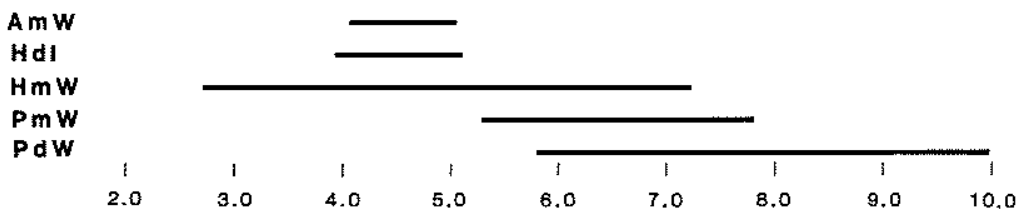

SEEDLING HEIGHT (M)

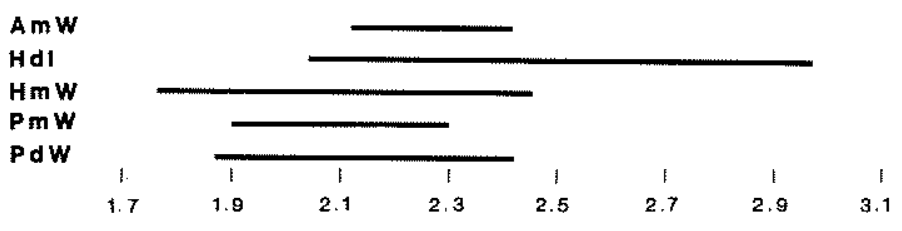

NODES EXPANDED

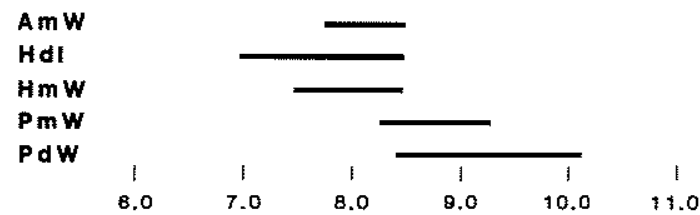

NUMBER OF LATERALS/NUMBER OF EXPANDED LEAVES ON DOMINANT SHOOT

A $m$ W

Hdl

$H \mathbf{m W}$

$P \mathbf{m} W$

$P d W$

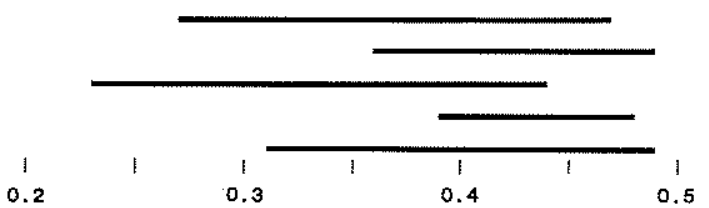

LENGTH LONGEST LATERAL SHOOT/SEEDLING HEIOHT

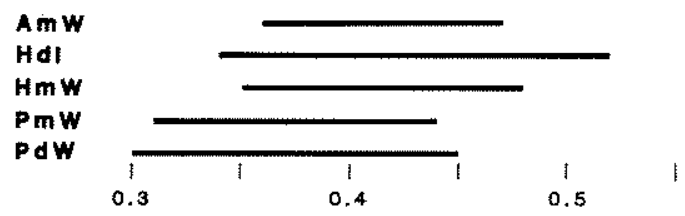

* SEedlings With INTRANOdes

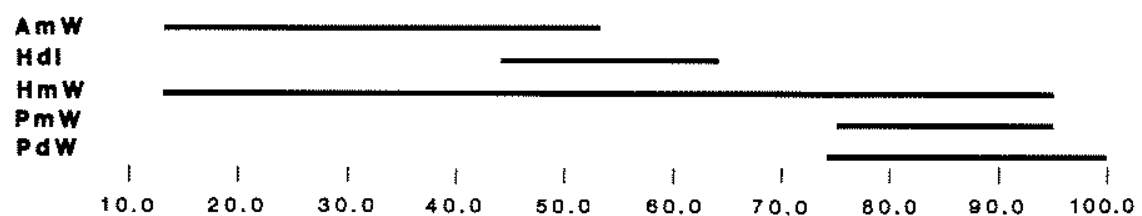

FIG. 4 - Ranges of progeny means by parent for six characters $(P=$ Eucalyptus pulchella, $\mathrm{A}=\mathrm{E}$. amygdalina, $\mathrm{H}=$ intermediate or hybrid, $m=$ mudstone, $d=$ dolerite, $W=$ Warrane, $I=$ Interlaken). 
E. amygdalina and E. pulchella at Waterworks, was also extreme in its seedling morphology, its mean values seldom lying between those of the progeny of the putative parents sampled at the

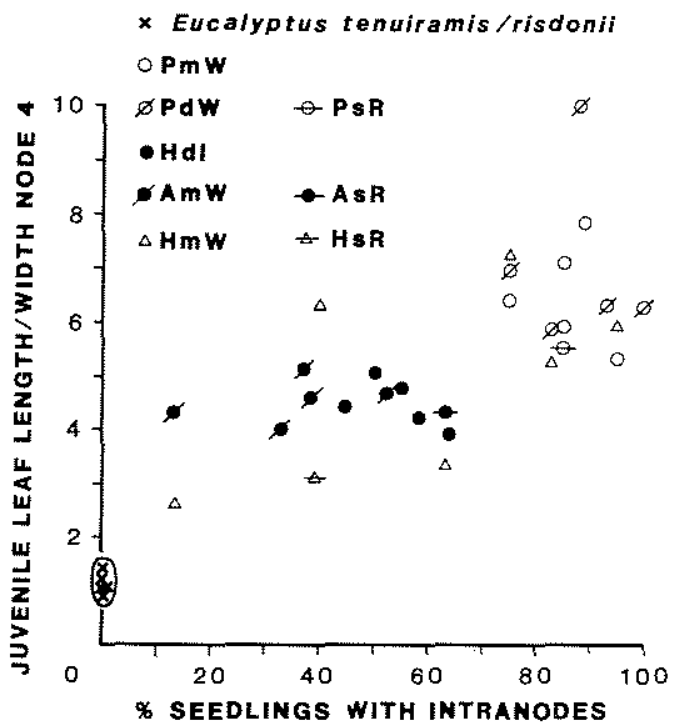

FIG. 5 - Progeny means by parent for the two seedling characters that best differentiate $\mathrm{E}$. amygdalina from E. pulchella $(P=$ Eucalyptus pulchella, $A=\mathrm{E}$. amygdalina, $H=$ intermediate or hybrid, $m=$ mudstone, $d=$ dolerite, $s=$ sandstone, $W=$ Warrane, $R=$ Waterworks, $I=$ Interlaken). same site (AsR and PsR, see fig. 5). HsR and at least one other putative hybrid from Warrane $(\mathrm{HmW})$ had progeny means that lay between those of $E$. amygdalina and those of $E$. tenuiramis/ risdonii. Sharp breaks between E. tenuiramis/ risdonii, E. amygdalina and E. pulchella progeny means are evident in figure 5 , with only the gap between $E$. amygdalina and the $E$. tenuiramis/ risdonii group being occupied by putative hybrids, none of which are from population $\mathrm{HdI}$.

\section{Seedling Variability}

The progenies of the presumed hybrids from Warrane ( $\mathrm{HmW}$ ) and the Waterworks (HsR) proved generally much more variable than those of any other populations included in the experiment (table 2). The significance of this general difference was tested by noting the number of times the coefficients of variation for the progenies of the eight trees from $\mathrm{HmW}$ and $\mathrm{HsR}$ fell in the top third of values for each of six characters (those in fig. 4 except intranode presence). The actual value was 22 with an expected value of 13.75 , giving a value of Chi-squared from a $2 \times 2$ contingency table of 9.5 (d.f. $=1, p<0.005$ ). The progenies from population $\mathrm{HdI}$ were no more variable than those from $\mathrm{AmW}$, PmW or PdW (table 1).

In the character that best differentiates the seedlings of Eucalyptus amygdalina and E. pulchella (leaf length/width at node four) the progenies of trees from each of AmW, Hdl, PmW and PdW vary in their variability, but it is only in progenies

TABLE 2

Means of progeny means and means of progeny coeficients of variation for selected seedling characters by group.

\begin{tabular}{|c|c|c|c|c|c|c|c|c|c|c|}
\hline & \multicolumn{2}{|c|}{ AmW (5) } & \multicolumn{2}{|c|}{ HdI (5) } & \multicolumn{2}{|c|}{ HmW (7) } & \multicolumn{2}{|c|}{ PmW (5) } & \multicolumn{2}{|c|}{ PdW (5) } \\
\hline & $\mathbf{M}$ & $\mathrm{CV}$ & $\mathbf{M}$ & $\mathrm{CV}$ & $\mathbf{M}$ & $\mathrm{CV}$ & $\mathbf{M}$ & CV & $\mathbf{M}$ & CV \\
\hline $\begin{array}{l}\text { Leaf length/width } \\
\text { node } 4\end{array}$ & 4.52 & 21.9 & 4.46 & 17.6 & 4.99 & 23.1 & 6.48 & 25.2 & 7.06 & 21.8 \\
\hline $\begin{array}{l}\text { Internode length } \\
(\mathrm{cm})\end{array}$ & 34.5 & 28.3 & 42.8 & 27.3 & 28.6 & 28.6 & 27.8 & 28.3 & 28.5 & 27.7 \\
\hline Height (m) & 2.26 & 0.316 & 2.59 & 0.276 & 2.04 & 0.314 & 2.12 & 0.334 & 2.18 & 0.283 \\
\hline $\begin{array}{l}\text { No. of expanded } \\
\text { nodes }\end{array}$ & 7.97 & 16.4 & 7.77 & 17.5 & 8.13 & 17.5 & 8.81 & 18.3 & 9.03 & 15.8 \\
\hline $\begin{array}{l}\text { No. of laterals/ } \\
\text { no. of nodes }\end{array}$ & 0.39 & 45.7 & 0.41 & 47.4 & 0.33 & 61.3 & 0.41 & 44.8 & 0.43 & 43.3 \\
\hline $\begin{array}{l}\text { Length longest } \\
\text { lateral/height }\end{array}$ & 0.46 & 31.4 & 0.45 & 33.6 & 0.43 & 40.5 & 0.37 & 36.6 & 0.37 & 32.6 \\
\hline
\end{tabular}




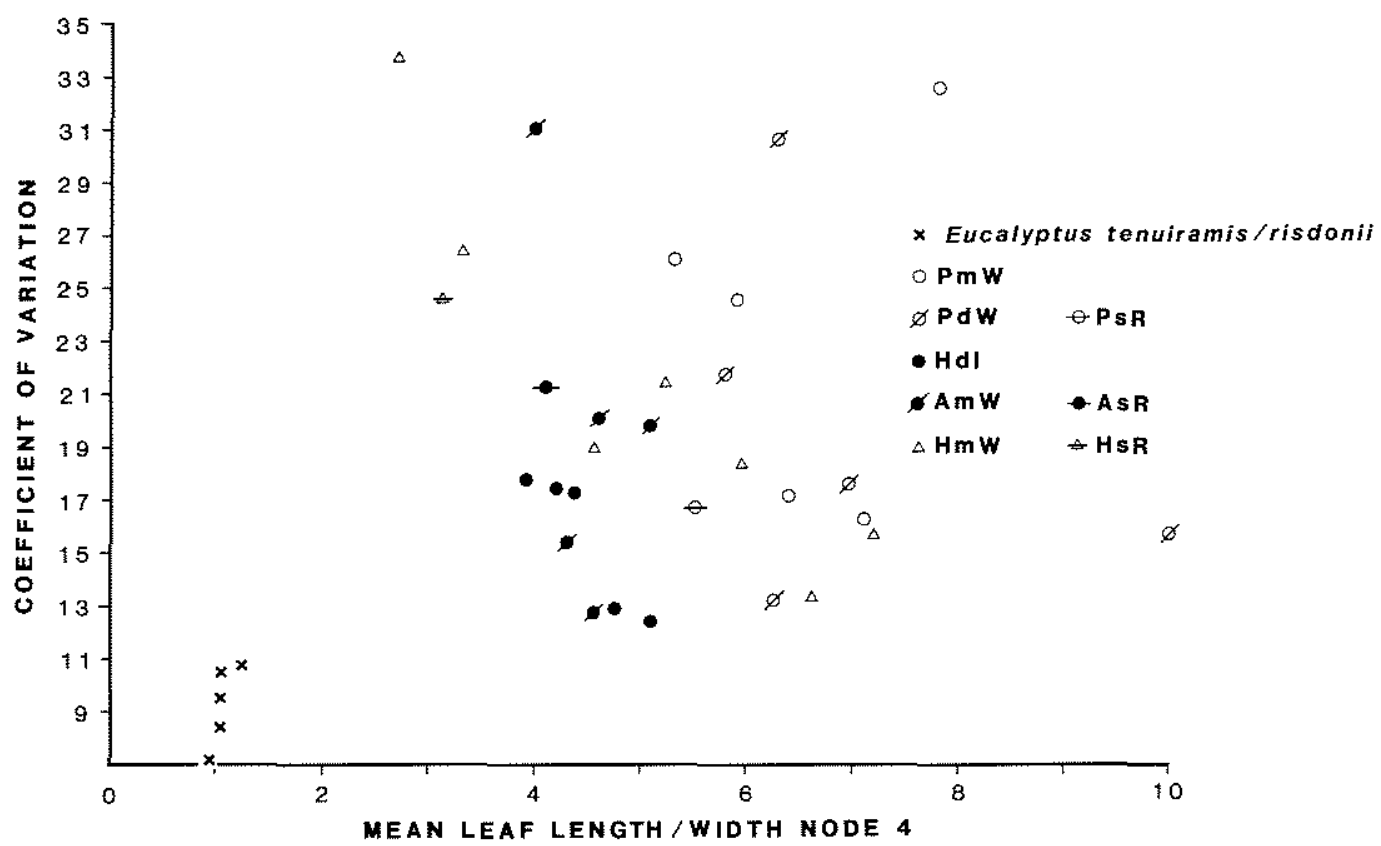

FIG.6 - Variotion in the variability about progeny means by parent for seedling leaf length/width at node four $(P=$ Fucalyptus vulchella, $A=\mathrm{E}$. amygdalina, $H=$ intermediate or hybrid, $m=$ mudstone, $d=$ dolerite, $s=$ sandstone, $W=$ Warrane, $R=$ Waterworks, $I=$ Intertaken).

intermediate between $E$. amygdalina and $E$. tenuiramis/ risdonii that there appears to be a peak of variability (see $\mathrm{HmW}$ and $\mathrm{HsR}$, fig. 6).

\section{DISCUSSION}

The experimental results do not necessarily support the hypothesis that Eucalyptus pulchella and E. amygdalina hybridize (Kirkpatrick et al. 1980, Potts \& Reid 1983), although they provide strong supporting evidence for hybridization between $E$. amygdalina and $E$. tenuiramis/ risdonii (Potts \& Reid 1985 b). There is no evidence in figures 5 and 6 to suggest that $E$. pulchella and $E$. amygdalina hybridize at the Waterworks or at Warrane. Progeny means from intermediate adult trees from these areas tended to lie close to either $E$. pulchella or E. amygdalina. This could result from advance generation hybridization or result from the backcrossing of F1 trees exclusively to one or other parent. However, the more likely interpretation is that individuals of E. pulchella can develop some rough bark, and that individuals of $E$. amygdalina can be relatively smooth-barked, either through selective processes in the absence of $E$. tenuiramis or E. risdonii (as in the case of $\mathrm{HdI}$ ), or as a result of the infiltration of genes from these latter two species, Eucalyptus pulchella and $E$. amygdalina differ little in seedling morphology when compared to their difference from $E$. tenuiramis/risdonii and the infiltration of genes from this complex may have an over-riding effect on progeny variability. This influence may account for the fairly high variability in several progenies from E. pulchella and E. amygdalina trees growing on mudstone at Warrane (fig. 6) and, unless more specific characters can be found, conclusive evidence of natural hybridization between $E$. amygdalina and $E$. pulchella requires the absence of $E$. risdonii and E. tenuiramis from the study area.

The isolated intermediate population (HdI) clearly has close affinities to $E$. amygdalina. The lack of intermediacy in juvenile characters and the low degree of progeny variability found for intermediate trees from this population would suggest that this stand has not arisen from recent hybridization through long distance dispersal nor does it appear to be a recent phantom hybrid population. This population is best regarded as the product of selection for narrow leaves and smooth bark within the gene-pool of E. amygdalina. Eucalyptus amygdalina and $E$. pulchella are very closely related (Pryor \& Johnson 1971, Marginson \& Ladiges 1982, Ladiges et al. 1983) and the convergence of some allopatric populations of $E$. amygdalina toward the $E$. pulchella phenotype (at 
least in adult characters) presents the possibility that the edaphic specialist $E$. pulchella is an extension of this trend.

\section{REFERENCES}

ADAMS, R.P., 1983: Infraspecific terpenoid variation in Juniperus scopulorum: evidence for Pleistocene refugia and recolonization in western North America. Taxon, 32: 830-846.

ASHTON, D.H. \& WILLIAMS, G, 1973: The occurrence of gum-topped stringybarks in the Trentham forest. Victorian Nat., 90: 90-92.

BARBER, H.N, 1955: Adaptive gene substitutions in Tasmanian eucalypts. I. Genes controlling the development of glaucousness. Evolution, 9: 1-14.

BARBER, H.N. \& JACKSON, W.D., 1957: Natural selection in action in Eucalyptus. Nature Lond., 179: 1267-1269.

BROWN, M.J.\& BAYLY-STARK, H.J., [979: Vegetation of Maria Isiand. Tasm. N.P.W.S. Tech. Rept 79/1.

CUNNINGHAM, T.M., 1960: The natural regeneration of Eucalyptus regnans. Bull. Sch. For., Univ. Melbourne. 1.

CURTIS, W.M. \& MORRIS, D.I., 1975: THE STUDENT'S FLORA OF TASMANIA. Part 1. Second edition. Government Printer, Hobart.

HARRIS, S. \& KIRKPATRICX, J.B., 1982: The vegetation of Schouten Island, Tasmania, Pap. Proc. R. Soc. Tasm., 116:117-141.

HOGG, A. \& KIRKPATRICK, J.B., 1974: The phytosociology and synecology of some southern Tasmanian eucalypt forests and woodlands. $J$. Biogeogr., 1: 227-245.

KIERNAN, K.W., 1983: Weathering evidence for an additional glacial stage in Tasmania. Austr. Geogr. Stud., 21: 197-220.

KIRKPATRICK, J.B., 1977a: Studies on some presumed hybrid populations in Eucalyptus. Proc. R. Soc. Vict., 89: 199-206.

KIRKPATRICK, J.B., 1977b: Eucalypt invasion in southern California. Austr. Geogr., 13: 387-393.

KIRKPATRICK, J.B., 1986:Tasmanian alpine biogeography and ecology and interpretations of the past, In Barlow, B.(Ed.): FLORA AND FAUNA OF ALPINE AUSTRALASIA. CSIRO, Canberra: $229-242$.

KIRKPATRICK, J.B. \& BACKHOUSE, S,, 1985: NATIVE TREES OF TASMANIA. Backhouse, Hobart.

KIRKPATRICK', J.B. \& BROWN, M.J., 1984: A numerical analysis of Tasmanian higher plant endemism. Bot. J. Soc. Lond., 88: 165-183.

KIRKPATRICK, J.B., BROWN, M.J. \& MOSCAL, A., 1980: THREATENED PLANTS OF THE TASMANIAN CENTRAL EAST COAST. Tasmanian Conservation Trust, Hobart.

KIRKPATRICK, J.B., SIMMONDS, D.\& PARSONS, R.F., 1973: The relationship of some popula. tions involving Eucalyptus cypellocarpa and $E$. globulus to the problem of phantom hybrids. New Phytol., 72: 867-876.
LADIGES, P.Y., HUMPHRIES, C.J. \& BROOKER, M.I.H., 1983: Cladistic relationships and biogeographic patterns in the peppermint group of Eucalypius (Informal subseries Amygdalinae, subgenus Monocalyptus) and the description of a new species, E. willisii. Aust. J. Bot., 31: 565-584.

MacPHAIL, M.K., 1979: Vegetation and climate in southern Tasmania since the last glaciation. Quat. Res., 11: 306-341.

MARGINSON, J.C.\&LADIGES, P.Y., 1982: Morphological and geographical disjunctions in forms of Eucalyptus nitida Hook. f. (Myrtaceae): with special reference to the evolutionary significance of Bass Strait, south-eastern Alstralia. Proc. $R$. Soc. Vict., 94: 155-167.

MORAN, G.F.\& HOPPER, S.D., 1983: Genetic diversity and the insular population structure of the rare granite rock species, Eucalyptus caesia Benth. Aust. J. Bot., 31: 161-172.

PARSONS, R.F. \& KIRKPATRICK, J.B., 1972: Possible phantom hybrids in Eucalyptus. New Phytol., 71: 1213-1219.

POTTS, B.M., 1986: The population dynamics and regeneration of a hybrid zone between Eucalyptus risdonii and E. amygdalina. Aust. J. Bot., 34: 305-329.

POTTS, B.M. \& REID, J.B., 1983: Hybridization between Eucalyptus obliqua L'Herit, and Eucalyptus pulchella Desf. Aust. J, Bot., 31 : 211-219.

POTTS, B.M. \& REID, J.B., 1985a: Variation in the Eucalyptus gunni-archeri complex. II. The origin of variation. Aust. J. Bot., 33: 337-359.

POTTS, B.M.\& REID, J.B., 1985b: Analysis of a hybrid swarm between Eucalyptus risdonii Hook. f. and E. amygdalina Labill. Aust. J. Bot., 33: 519-541.

POTTS, B.M. \& JACKSON, W.D., 1986: Evolutionary processes in the Tasmanian high altitude eucalypts. In Barlow, B. (Ed.): FLORA AND FAUNA OF ALPINE AUSTRALASIA. CSIRO, Canberra: 511-527.

PRYOR, L.D., 1951: A genetic analysis of some Eucalyptus species. Proc. Linn. Soc. N.S.W., 76: 140-148.

PRYOR, L.D., 1955: A hybrid swarm between Eucalyptus odorata Behr. and Eucalyptus leucoxylon F. Muell. Trans. R. Soc. S.A., 78: 92-96.

PRYOR, L.D.\& JOHNSON, L.A.S., 1971: A CLASSIFICATION OF THE EUCALYPTS. Australian National University Press, Canberra.

SCHLARBAUM, S.E., ADAMS, R.P., BAGLEY, W.T. \& WAYNE, W.J., 1982: Postglacial migration pathways of Quercus rubra L, northern red oak, as indicated by regional genetic variation patterns. Silvae Genetica, 31: 150-158.

SHAW, M.J., POTTS, B.M. \& REID, M.J., 1984: Variation within and between Eucalyptus nitida Hook. f. and E. coccifera Hook. f. Aust. J. Bot., 32: 641-654.

(accepted 24 June 1986) 